\title{
THE MOSSES OF LORD HOWE ISLAND
}

\author{
Helen P. Ramsay \\ (Accepted for publication 29.3.1983)
}

\begin{abstract}
Ramsay, Helen P. (School of Botany, University of New South Wales, Kensington, N.S.W. 2033) 1984. The Mosses of Lord Howe Island. Telopea 2(5): 549-558. - The mosses of Lord Howe Island are diverse with a close relationship to Australian and New Zealand species. Of the 105 species from 36 families, 21 species $(20 \%)$ are endemic. A checklist of species based on literature and collections in Australian herbaria is included together with a summary of their distribution patterns on the Island. This is a preliminary updating of previous records, not a taxonomic revision. The geographical relationships of the species are discussed.
\end{abstract}

\section{INTRODUCTION}

Here on this rich plateau may be found fern after fern and moss after moss that occur nowhere else in the world.

(Brotherus \& Watts 1915)

This description typifies the experience Rev. W.W. Watts had on his visit to Lord Howe Island, in particular Mt. Gower, in 1911 when he collected widely ferns, mosses, hepatics. His visit inspired a poem, part of which is quoted in Ramsay (1980), and led to a series of papers with lists and descriptions of new species of ferns, mosses and hepatics from the Island (Watts 1913, 1914, 1916; Brotherus \& Watts 1915; Stephani \& Watts 1914). Botanically, Lord Howe Island is of great interest because of the richness of the flora, which includes temperate and subtropical taxa with a high degree of endemism.

Island floras have always attracted interest for studies on species, their distribution and evolution in geographically isolated regions. Balgooy (1960, 1969, 1971), Whittier (1974) and Miller (1974) have been investigating island floras in the Pacific, particularly Polynesia, and their relationships. Miller (1974) states:

'Just recently I had occasion to review the bryoflora of Lord Howe Island, although some subtropical species are present, the flora is remarkably austral and antipodal. It is certainly not pait of the Polynesian subkingdom as it is usually considered - i.e. an attenuation of the Malaysian-Papuan floras and it is not typical of the flora of nearby Australia. The bryological flora confirms Takhtajan's view of an attenuation of the New Zealand flora even though the floristic overlap is not absolute.'

Takhtajan (1969) placed Lord Howe Island and Norfolk Island with New Zealand in his phytogeographical divisions of the Pacific Island groups, whilst Balgooy (1969) also concluded that 'the best solution is to maintain Lord Howe Island as a district within the New Zealand sub-region'. In this sub-region there is a high degree of correspondence between floristic limits and submarine geography and geology that are related to the geomorphic plates and great trenches of the ocean floor (Miller 1974).

As early as 1853, a short account of vegetation on Lord Howe Island was given by J. MacGillivray, an assistant surgeon on HMS "Herald", who surveyed the island. Literature related to Lord Howe Island is summarised in Pickard (1973) and Recker \& Ponder (1981). 
Although politically a part of New South Wales, the island has never had any land connection, being located on the eastern edge of the Australian continental shelf. It lies $790 \mathrm{~km}$ north-east of Sydney, some $550 \mathrm{~km}$ from the Australian coast (c. $31^{\circ} 30^{\prime} \mathrm{S}, 159^{\circ} 05^{\prime} \mathrm{E}$ ) in the Pacific Ocean. Lord Howe Island is considered to have arisen from an extensive undersea ridge and represents the eroded remnant of a large shield volcano (McDougall et al. 1981; Phipps 1981) of Tertiary age.

The climate is subtropical with no great range in temperature, being warmed by the South Equatorial Current. The average annual rainfall, mostly in winter, is stated as $1676 \mathrm{~mm}$, but believed to be far higher on the mountain summits. Soils are of two kinds:

(1) derived from Pleistocene carbonate sandstones that contain little volcanic material, on the northern part of the island; loose, sandy and dry with low moisture content (calcarenite).

(2) volcanic in origin, forming basalt soils on the eroded remnant of a volcanic peak of two ages - (a) northern part of Mt Lidgbird, older; (b) the soils making up most of Mt Lidgbird and Mt Gower are younger.

Two mountains, Mt Gower, $866 \mathrm{~m}$, and Mt Lidgbird, $765 \mathrm{~m}$, force warm moist air suddenly into colder altitudes where moisture is deposited as mist or rain (Edgecomb \& Bennett 1978). As a consequence, the summit of Mt Gower is covered by a gnarled mossy rainforest of great botanical, indeed biological interest, 'one of Nature's Botanic Gardens' (Brotherus \& Watts 1915). The moss forest at the summit of Mt Gower and Mt Lidgbird is composed of small trees, shrubs, palms and tree-ferns with an undergrowth of low ferns and sedges, the floor being mostly carpeted by mosses. Epiphytes cover almost every available space on larger plants (Oliver 1917).

The flora is heterogeneous, being related to Australian, New Zealand and Polynesian (Pacific Island) biota with the proportion of endemic forms in the Australian element well below that of the other two groups (Oliver 1917). However, in the non-endemic genera, Australian forms, 158 species, predominate, another 147 have Polynesian affinities and a further 109 occur in New Zealand. Thirty-three per cent of vascular plant species are endemic with related species evenly distributed between Polynesia, Australia and New Zealand (Oliver 1917). The relationship of the ferns is predominantly with the Australian region (Brownlie 1965). Non-endemic vascular plant species have mainly Australian affinities but the presence of a Malesian element distinguishes the Island flora from that of New Zealand and Australia (A.N. Rodd, pers. comm.). In spite of the close relationship to the Australian flora, most genera of angiosperms characteristic of Australia are absent from Lord Howe Island (Oliver 1917).

In a recent vegetation survey, 30 vegetation and six habitat classes, each dependent on soil, altitude and degree of exposure, have been mapped (Pickard $1973,1974,1983)$ for 178 native species of angiosperms, of which 55 species and 5 genera are endemic (Rodd 1974).

Knowledge of the bryophyte flora is still largely dependent on publications by Whitelegge (1892) and Brotherus \& Watts (1915) on mosses, and Stephani \& Watts (1914) on hepatics, where species collected by Watts during a seven-week stay on the island in 1911 are listed. No comprehensive collecting has been done since then although botanical visitors to the island have sometimes brought specimens home with them to Australian or overseas herbaria at various times.

This is a preliminary analysis of the mosses consisting of an updating of the literature records, the distribution being recorded from specimens located in the National Herbarium of New South Wales. Names applied to specimens have been accepted until a taxonomic revision by Vitt \& Ramsay can be completed. 


\section{DISTRIBUTION}

\section{Distribution on the island} (Fig. 1):

The distribution of moss species has been recorded in three geographical zones

1. Northern zone - In this region the highest points are Malabar (218 m) and Mt Eliza $(158 \mathrm{~m})$ representing part of the rim of an ancient volcano.

2. Central zone - This is the populated and agricultural area, being lowest in altitude on the island. It is bounded by a coral reef to the west while Intermediate Hill $(250 \mathrm{~m})$ on its south-eastern boundary, is surrounded by stratified limestone beds of marine origin and links with the foothills of Mt Lidgbird. This region is species rich because of its accessibility and the fact that it has been closely collected.

3. Mountain zone - The two peaks, (a) Mt Gower, $866 \mathrm{~m}$ (southernmost), and (b) $\mathrm{Mt}$ Lidgbird, $765 \mathrm{~m}$, form this region. They represent a later period of volcanic activity and have been heavily eroded.

0. Unspecified - Where no actual locality on the island is given.

The choice of zones has been made on the basis of topography and soils rather than other criteria, as collecting data have not been detailed enough to determine whether the vegetation zones of Pickard $(1974,1983)$ would be appropriate. The divisions chosen correspond closely to those mentioned by Oliver (1917, p.95).

Distribution of species across the island shows an interesting separation into those with widespread, and those with limited distribution (Table 1). Mt Gower and Mt Lidgbird species have been recorded separately where this is known, or simply from Zone 3 if not. Differences in numbers of species may be due primarily to Mt Lidgbird's inaccessibility to collectors, although its altitude is $100 \mathrm{~m}$ less than that of Mt Gower.

Table 1. Distribution of Species on Lord Howe Id.

\begin{tabular}{lrrrrrr}
\hline $\begin{array}{l}\text { Zone } \\
\text { No. species }\end{array}$ & 1 & 2 & $3 \mathrm{a}$ & $3 \mathrm{~b}$ & 3 & 0 \\
$\begin{array}{l}\text { Nos. in this } \\
\text { zone only }\end{array}$ & 26 & 56 & 37 & 6 & 13 & $\begin{array}{c}28 \\
\text { (unspecified) }\end{array}$ \\
\hline
\end{tabular}

\section{Relationships of Lord Howe Island mosses}

Whitelegge (1892) and Brotherus \& Watts (1915) between them listed 120 species of mosses of which 24 were reported as endemic. Brotherus \& Watts (1915) described 20 new species jointly and Brotherus two species. Some of these names have been reduced to synonymy and present studies that include data from collections not previously documented give the number of species as 105 in 58 genera and 36 families.

Relationships of these are interesting with 21 species (or 20\%) being endemic (see Ramsay 1984a). This is a low proportion when compared with some of the islands in the Pacific region, e.g. 60\% New Caledonia and Hawaii, 35\% Society Islands, 30\% New Zealand (Whittier 1974, Miller 1974). Most mosses have relationships with Australian species (60\%) (see Ramsay 1984a). These include both temperate and subtropical forms. The Australian species that are found on Lord Howe Island are primarily those that occur also in New Zealand (42 species or $37.5 \%$ ). Only 10 taxa are confined to Australia, New Zealand and Lord Howe Island, the other 32 are either cosmopolitan (12) or extend across the Southern Hemisphere, mainly the Pacific and South America. About 10 taxa are distributed 


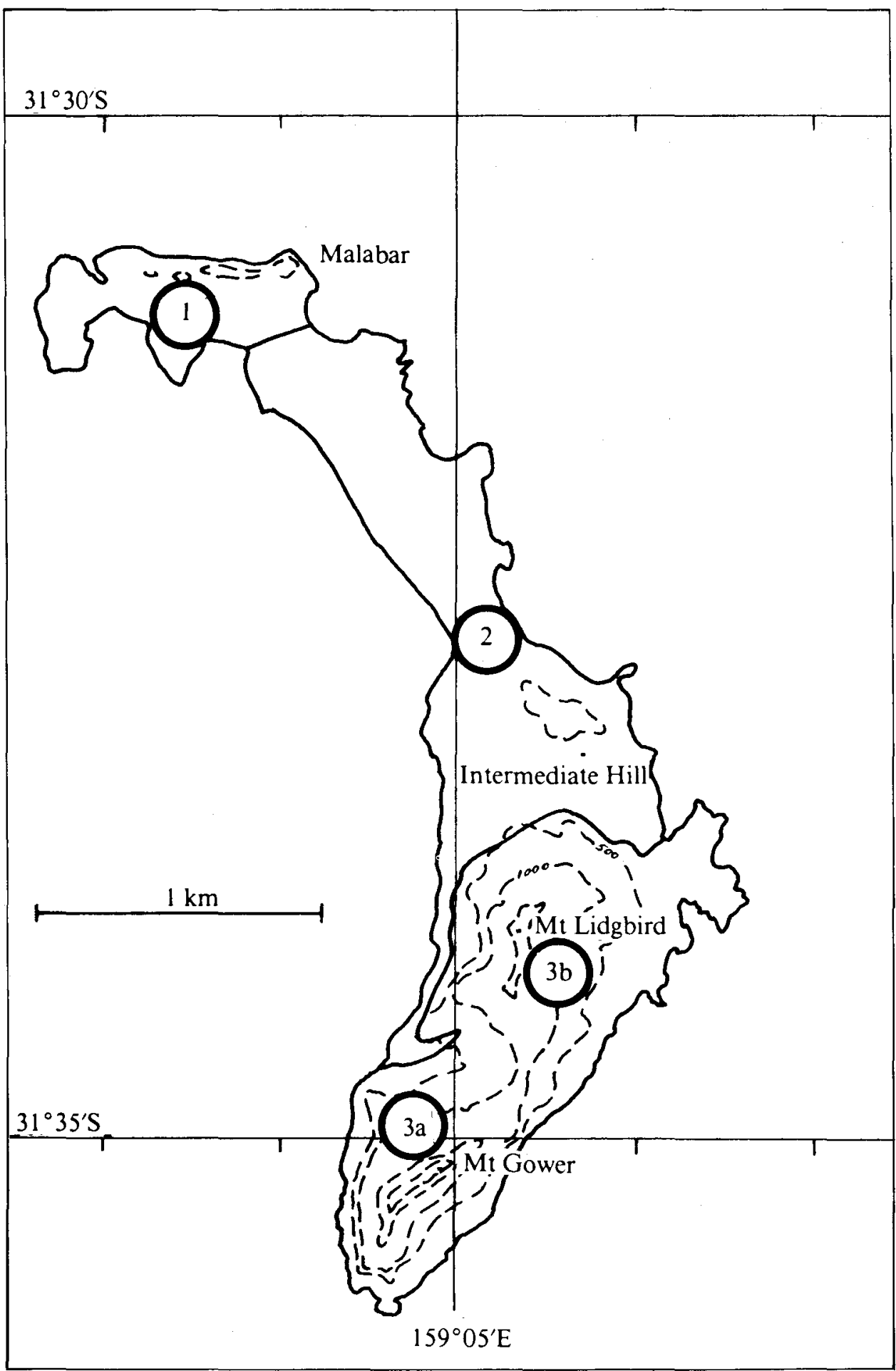

Fig. 1. Lord Howe Island showing division into areas for this study. 
only in Australia (2 New South Wales only, 2 or 3 Queensland only, 3 both New South Wales and Queensland) apart from Lord Howe Island.

The cosmopolitan species found on Lord Howe Island are: Ceratodon purpureus, Grimmia laevigata, G. pulvinata, Fissidens fontanus, Barbula calycina, Tortula pagorum, Weissia controversa, Funaria hygrometrica, Bryum argenteum, $B$. billardieri, B. capillare and Hypnum cupressiforme. Notable absences are Sphagnum spp. and Andreaea spp. as well as all the Polytrichaceae except Atrichum androgynum.

The distribution of mosses on Lord Howe Island supports the view that the relationships of vegetation are with Australia and New Zealand rather than other Pacific Island groups but, unlike the vascular plant species, the percentage of endemics is low as is the percentage with relationships to Polynesian species. There is no doubt that the flora will contain other species that have not yet been collected. Specimens available were obtained in only a few months of the year, and do not range over all seasons. Areas formerly inaccessible when previous collections were made may be reached in the future, possibly with use of helicopters. Collections in overseas herbaria may also be able to add new species and distribution data to our present limited knowledge. Work is continuing and Vitt \& Ramsay are preparing a complete revision of the moss flora to appear later.

\section{ACKNOWLEDGEMENTS}

The National Herbarium of New South Wales has been most co-operative in allowing me access to collections. J. Pickard and A. Rodd have helped in discussion of angiosperm vegetation and by providing a map. I am greatly indebted to these people and to those who have collected and deposited specimens of mosses from the island at various times in Australian herbaria. The work was made possible through funding from the Australian Biological Resources Study as part of the wider project on a Census of New South Wales mosses.

\section{LIST OF MOSSES FROM LORD HOWE ISLAND}

(Genera and species are listed alphabetically within families, which are numbered according to Crosby \& Magill 1981. The only synonyms included are those from Brotherus \& Watts 1915 original listing).

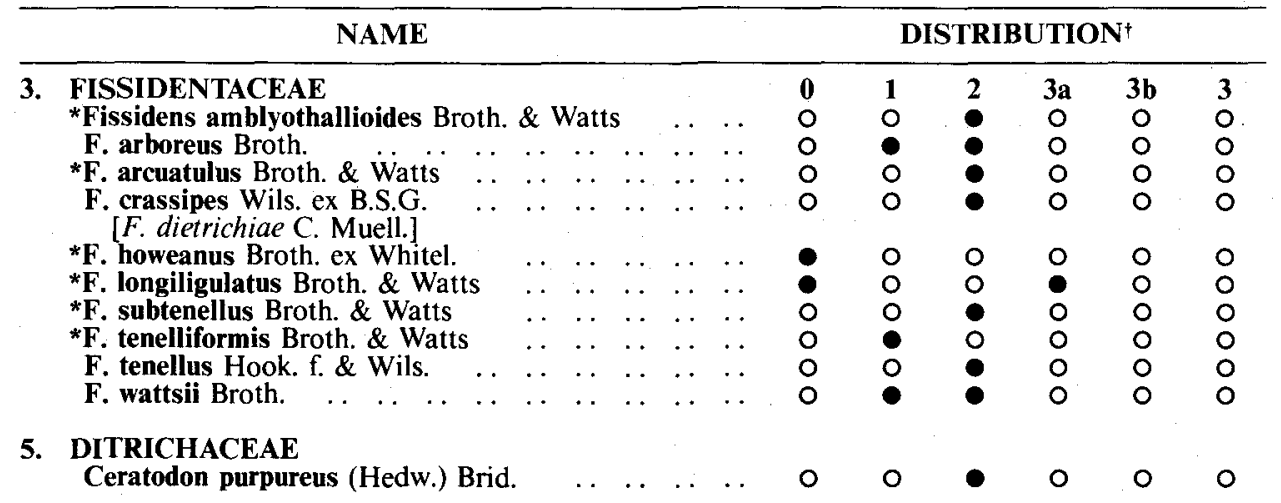

\footnotetext{
* Endemic species.
}

† Zones of occurrence: $\mathbf{0}$ - zone unspecified; 1 - northern zone; $\mathbf{2}$ - central zone; 3 - mountain zone (mountain not specified); 3a - Mt Gower; 3b - Mt Lidgbird. 
8. DICRANACEAE

Campylopus clavatus (R. Br.) Wils.

C. introflexus (Hedw.) Brid.

[C. pudicus (C. Muell.) Jaeg.]

C. pallidus Hook. f. \& Wils.

[C. woollsii (C. Muell.) Par.]

Dicnemoloma pallidum (Hook.) Wijk \& Marg.

[Leucoloma sieberianum (Hornsch.) Jaeg.]

Dicranoloma billardieri (Brid.) Par.

D. dicarpum (Nees) Par.

D. menziesii (Tayl.) Par.

[D. bartramioides (Broth.) Par.]

Holomitrium perichaetiale (Hook.) Brid.

H. perichaetiale (Hook.) Brid. var. robustum Broth. $\&$ Watts

Trematodon sp.

11. LEUCOBRYACEAE

Leucobryum candidum (P. Beauv.) Wils.

L. candidum var. pentastichum (Dozy \& Molk.) Dix. [L. speirostichum C. Muell. nom. nud.]

12. CALYMPERACEAE

*Syrrhopodon platyceri Mitt.

14. POTTIACEAE

Barbula calycina Schwaegr.

[Tortella calycina (Schwaegr.) Dix.]

Tortella cirrhata Broth.

[T. subflavovirens Broth. \& Watts]

Tortula pagorum (Milde) De Not.

[T. baileyi auct. non Broth.]

?Trichostomum sp.

$\begin{array}{llllllll}\text { Weissia controversa } \mathrm{Hedw} . & \cdots & \ldots & \ldots & . & \ldots & \ldots & 0\end{array}$ [W. flavipes Hook. f. \& Wils.]

15. GRIMMIACEAE

Grimmia laevigata (Brid.) Brid.

[G. campestris Burchell ex Hook.]

G. pulvinata (Hedw.) Sm. var. africana (Hedw.) Hook. [. \&. Cygnicolla Tayi., G. pulvinata var. obtusa (Brid.) Hueb.]

Racomitrium aciculum Dix.

19. FUNARIACEAE

Funaria hygrometrica Hedw. $[F$. hygrometrica Hedw. var. sphaerocarpa $\ddot{C}$. Muell.]

24. BRYACEAE

Bryum argenteum Hedw.

B. argenteum Hedw. var. lanatum ( $\ddot{\mathbb{P}}$. Beauv. $)$ Hampe

B. argenteum Hedw. var. niveum Wils.

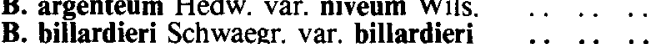
[B. leptothecium Tayl.]

B. campylothecium Tayl.

[B. howeanum Broth. \& Watts]

B. capillare Hedw.

[B. leptothecioides Broth. \& Watts,
B. whiteleggei Broth. nom. nud.]

B. coronatum Schwaegr.

[B. subatropurpureum C. Muell.]

B. dichotomum Hedw.

[B. aequicollum Broth. \& Watts,

B. philonotideum Broth. \& Watts]

B. erythrocarpoides C. Muell. \& Hampe

[B. diversinerve Broth. \& Watts] 
B. Jeucocanthum (Hampe) Mitt. [Rhodobryum leucocanthum Hampe]

B. limbifolium Broth. \& Watts

B. sauteri B.S.G.

25. LEPTOSTOMATACEAE

Leptostomum macrocarpum (Hedw.) Pyl.

32. RHIZOGONIACEAE

Mesochaete undulata Lindb.

Pyrrhobryum parramattense (C. Muell) Manue

[Rhizogonium parramattense (C. Muell.) Reichdi.]

33. HYPNODENDRACEAE

Braithwaitea sulcata (Hook.) Jaeg.

37. BARTRAMIACEAE

* Philonotis jardinii (Besch.) Par.

P. tenuis (Tayl.) Reichdt.

[P. pseudomollis (C. Muell.) Jaeg.]

38. SPIRIDENTACEAE

Spiridens vieillardii Schimp

[S. muelleri Hampe]

41. PTYCHOMITRIACEAE

Ptychomitrium australe (Hampe) Jaeg.

P. muelleri (Mitt.) Jaeg.

[Glyphomitrium commutatum (C. Muell.) Broth.,

$G$. howeanum (Hampe) Broth.]

42. ORTHOTRICHACEAE

Macromitrium brachypodium C. Muell. [M. brevisetaceum Hampe]

M. leratii Broth

M. peraristatum Broth $\begin{array}{llllllll}\cdots & \ldots & \ldots & \ldots & \ldots & \ldots & \ldots & \ldots\end{array}$

M. brevicaule (Besch.) Broth [M. subbrevicaule Broth. \& Watts, $M$. wattsii Broth.]

44. RACOPILACEAE

Racopilum cuspidigerum (Schwaegr.) Aongst. var. cuspidigerum [R. pacificum Besch.]

R. cuspidigerum (Schwaegr.) Aongst. var. convolutaceum (C. Muell.) Zant. \& Dijkstra [R. convolutaceum (C. Muell.) Reichdt.]

$\begin{array}{cccccc}0 & 1 & 2 & 3 a & 3 b & 3 \\ - & 0 & 0 & 0 & 0 & 0 \\ 0 & 0 & 0 & 0 & 0 & 0\end{array}$

51. PTYCHOMNIACEAE

Ptychomnion aciculare (Brid.) Mitt.

57. PTEROBRYACEAE

*Euptychium mucronatum Hampe

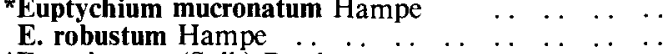

*E. setigerum (Sull.) Broth. [E. cuspidatum (Mitt.) Mitt.]

*Pterobryella praenitens (Hampe) C. Muell. [Hypnodendron praenitens (Hampe) Mitt.]

*Trachyloma wattsii Broth.

58. METEORIACEAE

Barbella enervis (Thwait. \& Mitt.) Fleisch. [Meteorium trichophoroides (C. Muell.) Mitt.]

Weymouthia mollis (Hedw.) Broth.

59. PHYLLOGONIACEAE

Catagonium politum (Hook. f. \& Wils.) Dus. ex Broth. Orthorrhynchium elegans (Hook. f. \& Wils.) Reichdt.

$\begin{array}{llllll}0 & 0 & 0 & 0 & 0 & 0 \\ 0 & 0 & 0 & 0 & 0 & 0\end{array}$ 


\section{NECKERACEAE}

Thamnobryum pumilum (Hook. f. \& Wils.) Nieuwl.

[Thamnium gracillimum (Hampe) Brorh. \& Watts]

$\begin{array}{llllll}0 & 1 & 2 & 3 \mathbf{a} & \mathbf{3 b} & 3 \\ 0 & \circ & \bullet & \bullet & 0 & \circ\end{array}$

61. LEMBOPHYLLACEAE

Camptochaete arbuscula ( $\mathrm{Sm}$.) Reichdt. var. deflexa (Wils.) Dix. [C. deflexa (Wils.) Jaeg.]

C. vaga (C.Muell.) Broth.

62. ECHINODIACEAE

Echinodium hispidum (Hook. f. \& Wils.) Reichdt. $\quad$.

65. HOOKERIACEAE

Achrophyllum dentatum (Hook. f. \& Wils.)

Vitt \& Crosby

[Pterygophyllum hepaticaefolium (Hampe \&

C. Muell.) Jaeg., Pterygophyllum nigellum (Hook. f. $\&$ Wils.) Mitt.]

*Distichophyllum longicuspis Broth.

[D. leucoloma Broth. nom. nud.]

68. HYPOPTERYGIACEAE

Cyathophorum bulbosum (Hedw.) C. Muell.

[C. pennatum (Labill.) Brid.]

Hypopterygium muelleri Hampe

[H. scottiae C.Muell.]

H. rotulatum (Hedw.) Brid.

72. THUIDIACEAE

Thuidium cymbifolium (Dozy \& Molk.) Dozy

$\begin{array}{lllll}\text { \& Molk. } & \text { furfurosum (Hook. f. \& Wils.) Reichdt. } & \ldots & \ldots & \ldots\end{array}$

T. protensulum C. Muell.

*T. trachypodioides Broth. \& Watts

74. BRACHYTHECIACEAE

Eurhynchium muriculatum (Hook. f. \& Wils.) Jaeg. [Rhynchostegiella muriculata (Hook. f. \& Wils.) Broth.]

*Oxyrrhynchium howeanum Broth. \& Watts

* Rhynchostegiella campylioides Broth. \& Watts

Rhynchostegium tenuifolium (Hedw.) Reichdt.

${ }^{*} \mathbf{R}$. tenuifolium (Hedw.) Reichdt. var. howeanum

Broth \& Watts

75. ENTODONTACEAE

Entodon pancherianus (Besch.) Jaeg.

$\begin{array}{cccccc}0 & 0 & 0 & \bullet & \bullet & 0 \\ 0 & 0 & 0 & \bullet & 0 & 0 \\ 0 & 0 & 0 & 0 & 0 & 0 \\ 0 & 0 & \bullet & 0 & 0 & 0 \\ 0 & 1 & 2 & 3 a & 3 b & 3 \\ 0 & 0 & 0 & \bullet & 0 & 0\end{array}$

77. SEMATOPHYLLACEAE

*Pungentella subfalcatulum (Broth. \& Watts.)

C. Muell.

[Rhaphidostegium subfalcatulum Broth. \& Watts]

Sematophyllum aciculum (Dix.) Dix.

[Rhapidostegium aciculum Broth. ex Dix.]

S. amoenum (Hedw.) Mitt.

[Rhaphidostegium callidioides (C. Muell.) Jaeg.,

Rhaphidorrhynchium callidioides (C. Muell.) Broth.]

S. contiguum (Mitt.) Mitt. [Rhaphidostegium contiguum (Mitt.) Par.]

*Trichosteleum muscicolum Broth

Wijkia extenuata (Brid.) Crum [Acanthocladium extenuatum (Brid.) Mitt.]

W. crossii (Broth.) Crum

78. HYPNACEAE

Ctenidium pubescens (Hook. f. \& Wils.) Broth.

*Ectropothecium howeanum Broth. \& Watts

$\begin{array}{ll}. . & \circ \\ . & 0\end{array}$

o

0

$\stackrel{0}{\circ}$ 


\begin{tabular}{|c|c|c|c|c|c|c|c|}
\hline & NAME & & & TR & JTI & & \\
\hline & 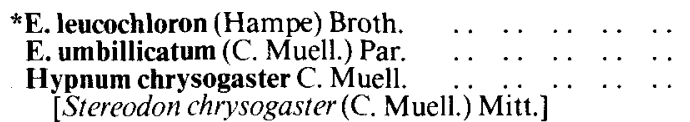 & $\begin{array}{l}\circ \\
0 \\
0\end{array}$ & $\begin{array}{l}\bullet \\
\circ \\
0\end{array}$ & $\begin{array}{l}\bullet \\
\circ \\
\circ\end{array}$ & $\begin{array}{l}\circ \\
\circ \\
0\end{array}$ & $\begin{array}{l}\circ \\
\circ \\
\bullet\end{array}$ & $\begin{array}{l}\circ \\
\circ \\
\circ\end{array}$ \\
\hline & H. cupressiforme Hedw. $\quad \ldots \quad \ldots \quad \ldots \ldots$ & 0 & 0 & 0 & - & - & $\mathrm{o}$ \\
\hline & 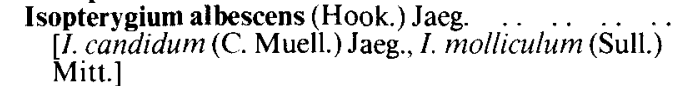 & 0 & 0 & - & 0 & 0 & 0 \\
\hline & I. howeanum Broth. \& Watts & 0 & 0 & - & 0 & 0 & 0 \\
\hline & Vesicularia montagnei (Bel.) Broth. & 0 & 0 & - & 0 & 0 & o \\
\hline 83. & $\begin{array}{l}\text { POLYTRICHACEAE } \\
\text { Atrichum androgynum (C. Muell.) Jaeg. } \\
\text { [Catharinea muelleri C. Muell. \& Hampe] }\end{array}$ & - & 0 & $\circ$ & - & 0 & o \\
\hline 84. & $\begin{array}{l}\text { DAWSONIACEAE } \\
\text { Dawsonia polytrichoides } \mathrm{R} . \mathrm{Br} . \ddagger\end{array}$ & - & 0 & 0 & 0 & 0 & 0 \\
\hline
\end{tabular}

$\$$ Although doubt has been expressed on the reliability of the original recora (Waits 1915 ) specimens collected in 1920 have been found which include specimens of Dawsonia polytrichoides amongst others but locality undefined.

\section{NOMINA NUDA}

The following species for which specimens have been located await attention to establish their relationships (*endemics)

* Leucobryum pseudocandidum Broth.

Amblystegium orbiculare Jaeg.

* Plagiothecium howeanum Jaeg.

\section{RECORDS NOT SUBSTANTIATED}

Records appearing in literature for the following have not been substantiated by specimens in Australian herbaria.

Rhodobrvum commersonil (Schwaegr.) Par.

Camptochaete gracilis (Hook. f. \& Wils.) Par.

Entodon pallidus Mitt.

Neckera trichophoroides C. Muell.

Racomitrium leptostomoides Förster

SYNONYMS

For the correct application of synonyms, see Ramsay, H.P. (1984), Census of New South Wales mosses, Telopea 2 (5): 455-533.

\section{REFERENCES †}

Balgooy, M.M.J. van (1960). A preliminary plant-geographical analysis of the Pacific. Blumea 10 (2): 385-430.

Balgooy, M.M.J. van (1969). A study of the diversity of island floras. Blumea 17: 139-178.

Balgooy, M.M.J. van (1971). Plant geography of the Pacific as based on a census of phanerogam genera. Blumea 6 suppl.: 1-222.

Brownlie, G. (1965). The geographical affinities of the South Pacific island fern floras. Pacific Sci. 19: 210-219.

Clark, S.S. (1974). Pattern analysis of vegetation. Appendix D. In Recher, H.F. and S.S. Clark, (eds), 'Environmental Survey of Lord Howe Island.' (Govt Printer: Sydney.) pp. 37-46.

† For a full reference list see Ramsay, H.P. (1984), Census of New South Wales mosses, Telopea 2 (5): 455-533. 
Edgecombe, J. \& Bennett, I. (1978). 'Discovering Lord Howe Island.' (Pacific Maps: Sydney.) pp.1-90.

Förster, J.B. (1901). Rhacomitrium leptostomoides J.B. Förster nov. spec. Ann. Natur. Hofmus. Wien 16: 71.

Good, R. (1957). Some problems of southern floras with special reference to Australasia. Austral. J. Sci. 20: 41-44.

MacGillivray, J. (1854). Letter from John MacGillivray Esq., Naturalist of H.M. Surveying ship 'Herald' commanded by Captain Denham; dated Sydney, March 3rd 1854. Hooker's J. Bot. Kew Gard. Misc. 6: 353-363.

McDougall, I., Embleton, B.J.J. \& Stone, D.B. (1981). Origin and Evolution. [In Recher, H.F. and W.F. Ponder (eds), Lord Howe Island.] Occas. Rep. Austral. Mus. 1: 6.

Miller, H.A. (1974). A bryological evaluation of the Polynesian subkingdom. Soc. Bot. Fr. Coll. Bryol. 121: 287-293.

Oliver, W.R.B. (1917). Vegetation and flora of Lord Howe Island. Trans. \& Proc. New Zealand Inst. 49: 94-161.

Paramov, S.J. (1963). Lord Howe Island, the riddle of the Pacific. Part iii. Pacific Sci. 17: 361-373.

Phipps, C.V.G. (1981). Geology. [In Recher, H.F. and W.F. Ponder (eds), Lord Howe Island.] Occas. Rep. Austral. Mus. 1: 6-8.

Pickard, J. (1973). An annotated botanical bibliography of Lord Howe Island. Contr. New South Wales Natl. Herb. 4(7): 470-491.

Pickard, J. (1974). Vegetation map of Lord Howe Island. In Recher, H.F. and S.S. Clark, (eds), 'Environmental Survey of Lord Howe Island.' (Govt Printer: Sydney.) pp. 1-27.

Pickard, J. (1983). Vegetation of Lord Howe Island. Cunninghamia 1(2): 133-265, Map.

Ponder, W.F. (1981). Biogeography of the non-marine fauna and flora. [In Recher, H.F. and W.F. Ponder (eds), Lord Howe Island.] Occas. Rep. Austral. Mus. 1: 51 .

Ramsay, H.P. (1981). Bryophytes. [In Recher, H.F. and W.F. Ponder (eds), Lord Howe Island.] Occas. Rep. Austral. Mus. 1: 37-38.

Recher, H.F. \& Clarke, S.S. (eds) (1974). 'Environmental Survey of Lord Howe Island.' (Govt Printer: Sydney.)

Recher, H.F. \& Ponder, W.F. (eds) (1981). Lord Howe Island. Occas. Rep. Austral. Mus. 1.

Rodd, A.N. (1974). Vegetation. In Recher, H.F. and S.S Clark (eds), 'An Environmental Survey of Lord Howe Island.' (Govt Printer: Sydney.) pp. 21-26.

Stephani, F. \& Watts, W.W. (1914). Hepaticae Australes. Proc. Roy. Soc. New South Wales 48: 94-135.

Takhtajan, A. (1969). 'Flowering Plants, Origin and Dispersal.' (Oliver and Boyd: Edinburgh.)

Watts, W.W. (1912). The ferns of Lord Howe Island. Proc. Linn. Soc. New South Wales 37: 395-403.

Watts, W.W. (1914). Additional notes on the ferns of Lord Howe Island. Proc. Linn. Soc. New South Wales 39: 257-26́2.

Watts, W.W. (1915). Two Lord Howe Island Polypodia. Proc. Roy. Soc. New South Wales 49: 385-388.

Whitelegge, T. (1892). A list of 20 species of mosses collected on Lord Howe Island. Proc. Linn. Soc. New South Wales 7: 277.

Whittier, H.O. (1974). The amphigenous bryoflora of French Polynesia. Soc. Bot. Fr. Coll. Bryol. 121: 277-286. 